\title{
街路の形態的特性に基づく媒介中心性と 形成年代との関係性に関する研究
}

\author{
高野 裕作 1 ・佐々木 葉 2 \\ 1 正会員 (公財)日本都市センター（†102-0093 東京都千代田区平河町 2-4-1） \\ E-mail: y-takano@toshi.or.jp \\ 2フェロー会員 早稲田大学教授 理工学術院 社会環境工学科（†169-8555 東京都新宿区大久保 3-4-1） \\ E-mail: yoh@waseda.jp
}

\begin{abstract}
現在の都市空間を構成する街路は, 近代化以前から存在する道筋や都市計画によって建設された街路, スプロールによって自然発生的に形成された街路など様々な形成時期, 経緯によるものがある。またそれ らは幹線道路や近隣商店街，住宅街の区画街路など多様な利用特性を有しており，これらの関係性を明ら かにすることは今後の街路整備, 都市計画を検討するうえで, 有用であると考えられる.

本研究では東京の都市拡大によって市街地が形成された目黒区・渋谷区を中心とした地域を対象として, 旧版地形図の分析より個々の街路の形成年代を, Space Syntax 理論を用いて経路としての利用特性(媒介中 心性：Choice)を分析し，これらの関係を相関比を用いて明らかにした結果，形成年代の古い街路が主に近 隣スケールにおいて媒介中心性が高いことが明らかとなった.
\end{abstract}

Key Words : historical landscape characterization, street pattern, space syntax, choice

\section{1. 序論}

\section{(1) 研究の背景 ·目的}

現在の都市空間を構成する街路には，近代化以前から 存在する道筋や都市計画によって建設された街路，スプ ロールによって自然発生的に形成された街路など様々な 形成時期, 経緯によるものがある. またこれらは幹線道 路や近隣の商店街の街路, 住宅街の区画街路など，ネッ トワーク上の位置づけに対応した様々な利用特性を有し ている。ここでいう利用特性とは，単純な交通量や利用 頻度の多葟だけでなく, 近隣から広域まで様々な距離圈 域における移動の特性の際も含まれるものである。この ような街路の形成時期，経緯と利用特性との間には一定 の対応関係があると思われる。

東京の街路パターンは，都心部については江戸期に建 設された骨格構造(下町-山の手)を引き継ぎながら，近代 化の過程で特に震災, 戦災の復興事業を通じて現在の構 造が形成されてきたことが知られている，それに対して 郊外部では，特に関東大震災以後の人口増大に伴って近 郊の農村地域が急速に市街地化し, その拡大の過程で, 一部では区画整理などで良好な住環境が形成され現在ま で維持されているところもあるが，大部分では計画的に 街路などの都市基盤が整備されないまま市街地化したた
め，狭监で複雑な街路パターンが形成された。このよう な地区ではその街路パターンに起因して防災上の脆弱性 などの課題が指摘される一方，街路の形態的特性は利用 特性を規定するものでもあり，地区の固有性の観点から も街路パターンの改変には慎重な検討が求められる.

こうした地域において，現在の街路パターンを構成し ている個々の街路について，その形成経緯と利用特性の 関係性を明らかにすることは，今後の新設や改築を含め た街路整備ならびに都市計画を検討するうえで，有用で あると思われる。

本研究では上述のように東京の都市拡大の過程で市街 地が形成された地域として，渋谷区，目黒区の全域と世 田谷区の一部を含む範囲を対象として, 街路パターンの 変遷を旧版地形図を基に分析し，現在の街路パターンを 構成する街路の形成年代を特定する.

なお，街路の利用特性には冒頭に挙げたような定性 的・機能的な分類や，交通量や移動軌跡など観測データ に基づく実態的な特性などが一般的に議論されるが，本 研究では Space Syntax 理論によって導かれる Choice とい う指標を用いて，街路の経路として利用しやすさ，すな わち媒介中心性の特性として扱うこととする. 算出方法 は後述するが，この指標は街路の形態的な接続特性のみ から求められるため, 全ての街路空間に対して指標が算 
出され，実利用データの整備が不十分な細街路，更には 過去に至るまで比較可能なものである．またこの指標は 解析範囲の規模を任意に設定することができ，近隣から 広域まで様々な移動の特性に対応した指標を算出できる。

本研究では街路の形成年代と利用特性(媒介中心性指 標)との関係性を分析し，具体的には形成年代の古い街 路ほど媒介中心性が平均的に高いこと，またその傾向に 対する分散は近隣スケールにおける指標よりも広域スケ 一ルの方が大きいことを明らかにする。これらは各章の 考察・結論で述べる通り，一見当たり前の街路網形成の 論理によるものと考えられるが，定量的な指標によって 統計的に検証する事によって, 街路の形成過程に関する 基礎的な知見を提示寸ることが本研究の目的である.

\section{(2) 研究の位置づけ}

\section{a) 既往研究}

都市・地域の街路パターンの経年的な変化は，いくつ かの時点の街路パターンの特性を定量的に分析し，それ らを年代間で比較することで明らかにされる. その指標 としては地域内の街路の総延長や面積といった物理的な 指標や, フラクタル次元などの街路網の幾何学的な形状 特性の指標, グラフ理論を援用して求められる街路ネッ トワークの接続特性の指標がある.

物理的な指標を用いたものとして，小場瀬 ${ }^{11}$ は世田谷 区の北沢と経堂の 2 地区に対して, 明治 23 年から昭和 54 年までの街路の変化について地形図を用いた分析を 行った. 小場瀬は地区内の街路を「地区集散道路」と

「突込久型道路」という利用特性に分類し, 昭和 54 年 時点で地区集散道路として機能している幅員 $6 \mathrm{~m}$ 前後の 街路が明治期から変わらずに存在していること, 戦後に 突込み型街路が急増していることなどを，街路延長と街 区面積の変化から明らかにしている.

街路のネットワーク特性を分析する手法としては，本 研究で用いる Space Syntax 理論を用いるものと, 一般的 なグラフ理論を用いるものがある.

前者では, 西村ら ${ }^{2}$ は江戸・東京の街路パターンの変 化を Axial 分析の Integration 值を用いて解析し, $250 \mathrm{~m}$ 四 方のメッシュ単位で年代間の指標を比較することで，各 年代に行われた都市計画による街路パターンへの影響を 明らかにしている.木川らは Integration 值の Local と Global の二つの解析範囲の特性の相関性に着目して都市 エントロピー指数という指標を提案し，パリ ${ }^{3)}$ ，京都 ${ }^{4}$, 大津 ${ }^{5)}$ ，台北 9などさまざまな都市に適用してその歴史 的な変遷と都市計画との関係性を考察している. 猪八重 らわも都市エントロピー指数を用いて，佐賀市周辺の都 市域の拡大について分析している.

後者では, 福山・羽藤 8)はバルセロナ旧市街の歴史的 発展過程を，媒介中心性指標を $250 \mathrm{~m}, 500 \mathrm{~m}, 1000 \mathrm{~m}$ と行
動圈域ごとに算出し, 各年代間に行われた都市計画との 関係を考察している，特に広場に着目し，各年代に形成 された広場がどのような行動圈域において利用されるポ テンシャルを持っているかを分析し, 近年の都市再生に よって新たに整備された広場の配置などを評価している。

\section{b) 歴史的景観キャラクタライゼーション(HLC)}

上記の研究は主に変化に着目したものであるが，過去 から現在まで変化しない部分に着目する手法として歴史 的景観キャラクタライゼーション(HLC)がある．HLC は， ある広がりを持ったエリアのランドスケープの歴史的特 性を評価する手法であり, 主に英国で発展し, ランドス ケープアセスメントの場面などで活用されている9!.

HLC では主に土地利用に着目して，その土地の成立 から現在まで変化せずに存在する時間の深さ(Time-depth) を特定することで歴史的価值の蓄積を評価する．我が国 の学術研究では松倉・宮脇 ${ }^{10)}$, 北岡・宮脇 ${ }^{11) な と ゙ い く つ ~}$ かの論文で適用され，東京の下町地域や鎌倉の土地や街 路, 寺院などの歴史的価值を明らかにしている.

\section{c) 本研究の位置づけ}

本研究は, 街路の利用特性と形成年代との関係性を分 析するもので, 目的は先述の小場瀬の研究に共通寸ると ころがあるが，手法として HLC, Space Syntaxによって定 量的に指標を求め, GIS を用いて地理空間分析を行う点 に特徴がある.また上述の既往研究の多くは街路パター ンの変化に注目しているが，本研究では HLC の手法を 援用して現在まで变わらない部分に着目して街路形成年 代を特定し，形成年代自体を変数として， Space Syntax 理論によって求めた媒介中心性指標との関係性を統計的 に分析し，その傾向を基礎的な知見として提示するもの である。

\section{(3) 本論の構成}

2 章では研究の枠組みとして, 対象地の概要および調 查対象年代と, 研究手法である Space Syntax 理論の Segment Anguler 分析について説明する. 3 章では HLCを 用いた街路パターンの変遷分析を行い, その変化の基礎 的な分析を行う. 4 章では Segment Anguler 分析によって 各年代の街路パターンの利用特性を解析し, Choice 值の 変化について分析する. 5 章では 2015 年現在の街路パタ ーンについて, 各街路の形成年代と媒介中心性との関係 性を, 相関比 $\eta^{2}$ 用いて解析し, 明らかにする. 6 章で 結語を述べる.

\section{2. 研究の枠組み}

\section{(1) 研究対象地域}

本研究では東京都渋谷区と目黒区の全域・世田谷区の 


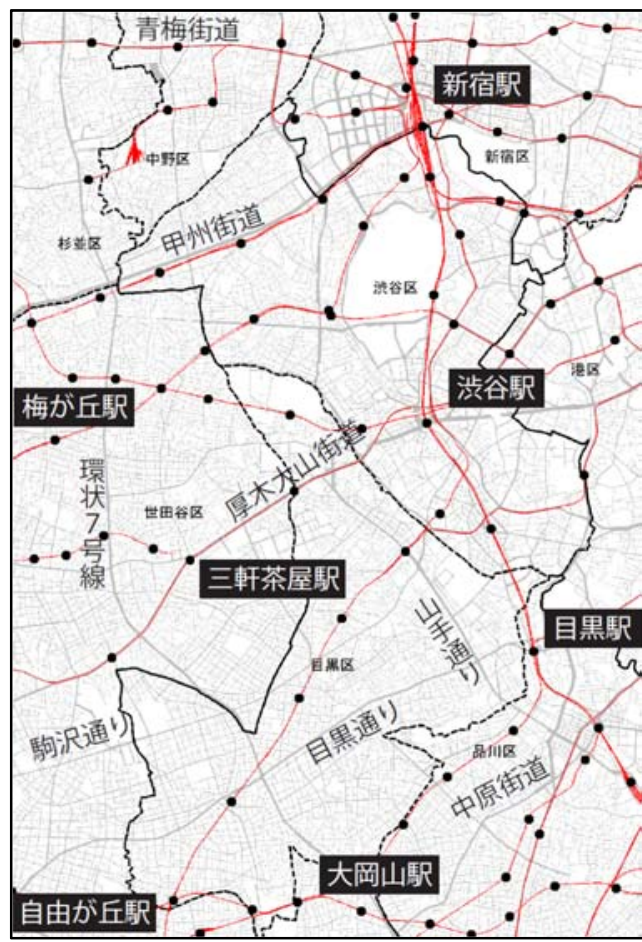

図-1 研究対象地域の概要

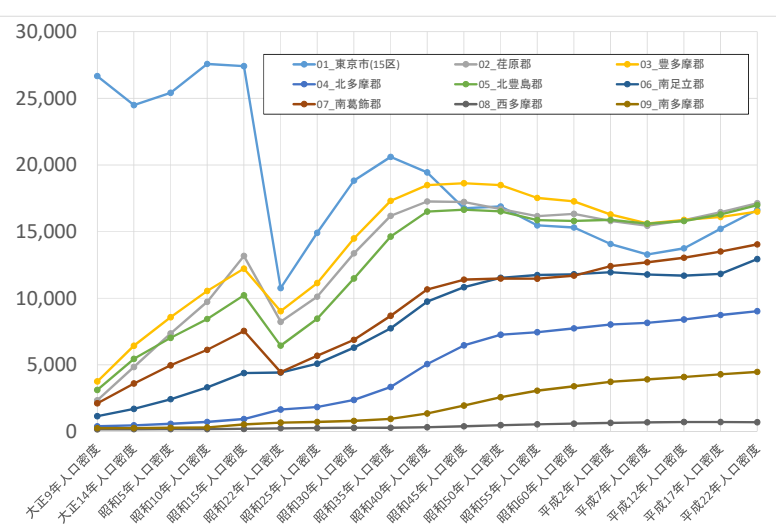

図-2 東京都地域別人口密度推移(旧市郡域に再集計)

一部を含む，図-1 に示す範囲に含まれる街路を分析の 対象とする.この範囲の西端・南端は後述する地形困の 図郭の区切りによるものであり，対象とする最も古い年 代において $1 / 10000$ 地形図が発行されている端部でもあ る. 東〜北の端部は概ね渋谷・目黒区の区界を含みなが ら SS 理論の分析においてネットワークの完結性が求め られることから，主要な街路や大規模な敷地を境界とし て設定した.

江戸・東京の都心部の街路・土地利用の変遷・歴史に ついは，山の手地域を中心とした事例としては槇らの

「見えがくれする都市」12など，下町地域については先 述の HLC を用いた研究など, 数多くの研究がなされて いるが，郊外部について定量的な観点で分析した研究は 少ない。図-2 の国勢調査をもとにした旧市郡別の人口 密度の推移に示すとおり，関東大震災の前後で旧東京市 15 区の範囲の人口密度はほぼ横ばい(震災によって減少
したのち震災前の水準に回復)であったのに対して，本 研究対象範囲を含む荏原郡，豊多摩郡は戦前から急激に 人口が増加した。 それに伴って市街地が急速に形成され， 昭和 7 年に東京市は現在の 23 区の範囲(注1)に市域を拡大 したが，その市街地化の様相は一様ではなく，地区ごと に固有の経緯と形態を有している。本研究では広域にわ たって街路一本一本の詳細の単位で変遷を分析すること で，これまで明らかにされていなかった利用特性と形成 年代との関係性を分析する.

\section{(2) 分析資料 · 対象年代}

\section{a) 分析に用いる地図資料}

本研究の HLC 分析にあたっては, 対象地域をカバー し尚且つ個別街路の形態を把握することができる旧版地 形図として，縮尺 1/10000 の地形図を使用する。東京周 辺における市街図としての 1/10000 地形図は，陸軍陸地 測量部によって明治 42 年前後にその初版が測量・発行 され，以後昭和 30 年前後の第六次に至るまで修正測 図・発行がなされてきた。1/10000 地形図は，測量・作 図の精度にやや不鮮明な部分があるものの，現代の街路 地困(1/2500)に記載されている細街路の存在とその位相 的な接続関係まで確認することができることから，形成 年代を特定することは可能であると判断した(注2)

\section{b) 分析対象年代}

本研究では対象地域の都市化に関わる時代背景と，入 手可能な地困の制約などを鑑み，[1]近代化黎明期とし て 1909(明治 42)年，[2]関東大震災直前である 1923(大正 12)年，[3]震災復興から戦前の都市拡大期として 1937(昭 和 12)年, [4]戦中〜戦災復興を経た 1957(昭和 32)年, [5] 高度経済成長期を経た 1984(昭和 59)年，[6]バブル崩壊か ら現在を反映する 2015(平成 27)年の 6 年代を分析対象と した(注3).

\section{(3) Segment Anguler 分析}

\section{a) Segment Anguler 分析の概要}

Hillier and Hanson ${ }^{13)}$ とよって提唱・確立された Space Syn$\operatorname{tax}$ 理論は，建築内部空間から都市の街路ネットワーク に至るまでさまざまなスケールの空間の構造を人間の認 知に基づく単位で解析し，その利用特性を明らかにする 理論・手法である.わが国でも 1990 年代から都市・建 築の学術研究で適用例があり ${ }^{14)}$, 都市を対象とした研究 では街路を視線の見通し線(Axial Line)によって分節して その位相的なつながりを元に解析する Axial 分析と, そ れによって求められる Integration 值が多く用いられてき た.

海外での研究 15 や実務への適用では，より詳細な空間 単位と交差角度の重み付けを考慮した，Segment Anguler 分析が用いられることが多くなり，特にその中で求めら 
れる Choice という指標が，都市の交通流動を説明する 上で強力な変数として扱われており, わが国の学術研究

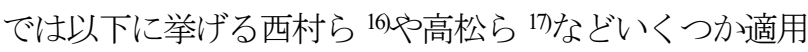
例がある.

西村らは愛知県豊田市を対象としてプローブカー調査 による通行実績データと Segment Angler 分析によって求 めた指標との関係を GIS を用いて対応させ，近接性 (Integration) が実利用の多さを，媒介性(Choice)が OD 特性 の多様さに関係が強いことを実証的に明らかにした。こ の研究では, 街路の利用特性の実態が従来の交通工学で 用いられてきた旅行時間の最小化という原則のみで説明 できるものではなく，接続特性に基づく多様な利用特性 に即したネットワーク計画の重要性を示唆している. 高 松らは千葉県鎌厅谷市を対象として, Segment-Anguler 分 析によって求められた指標を用いて地点ごとの交通事故 リスクを推定するモデルを導出し，交通事故が多発する 地点を一定程度説明することができるとしている.

Segment-Angler 分析は街路空間を交差点や屈曲するポ イントで Segment という単位に分節し, Segment を頂点 とし，その接続関係を辺とするグラフにモデル化する手 法である. 図-3に示寸通り，隣接する Segment 同士の距 離は交差角度 90 度を Depth=1.0 と換算して重み付けされ 離れた Segment 間の距離は通過する Segment での交差角 度の変化を累積して計算する。

\section{b) Choice の算出方法と解析範囲(Radius)の設定}

街路ネットワークの形態的特性を表寸指標は，その地 点を起終点として他の地点とどれだけ近接しているかと いう特性(近接性 : Closeness) と, 他の地点同士の移動に 際してその地点がどれだけ経路として使われるかという 特性(媒介性：Betweenness)の二つがある. Space Syntax 理 論では前者は Integration, 後者は Choice という指標がそ れぞれ対応しており, 本研究では Choiceに着目する.

Choice は解析範囲に含まれる他のセグメント同士を最 小の累積交差角度で結ぶ経路のうち, 当該セグメントを 通る経路の数を単純に数え上げたものである。この指 標は複数の道路が合流・分散する地点や河川を渡る橋梁, 鉄道を横断する踏切など, 複数の領域間の移動で重要な 地点において高くなる傾向があり, 交通モードが大きく 変化した本研究の対象年代を通じても普遍的な, 街路ネ ットワークの形態が持つポテンシャルとしての利用特性 と解棌することができる.

解析範囲(Space Syntax の研究では Radius と称する)は, 分析対象範囲全ての Segment 同士の移動を考慮する Global な解析と, 各セグメントから任意の距離を設定し てそれに含まれる Segment 同士の移動を考慮する Local な解析がある. Radius の設定に当たっては前述の累積交 差角度によって設定する場合と経路距離によって設定す る場合があるが, 本研究では経路距離として
表-1 Node Count と Choice $の$ 平均值

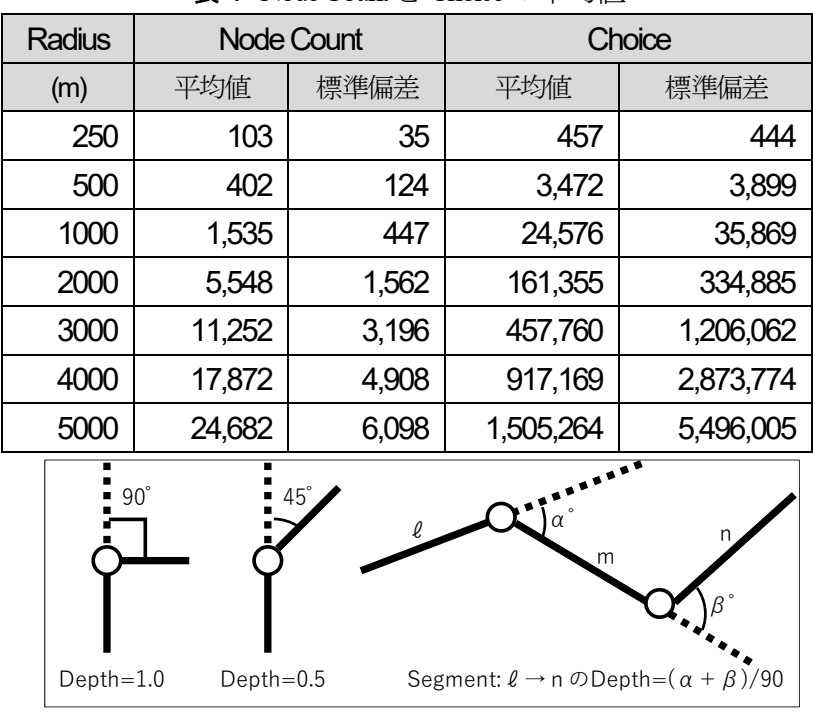

図-3 Segment間の Depth の算出方法

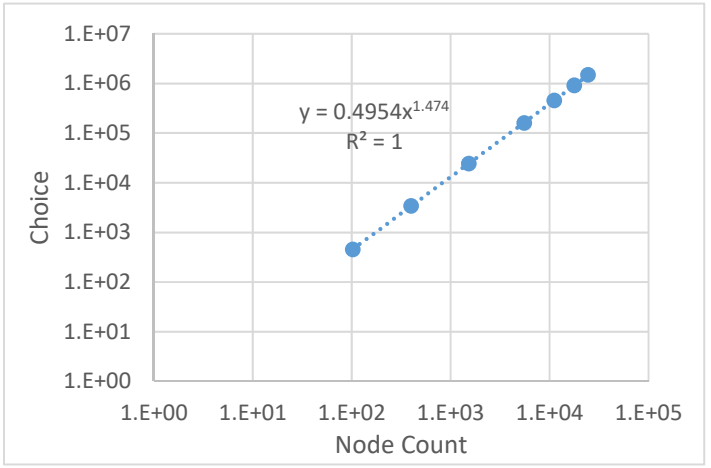

図-4 NodeCount と Choice 平均值の関係

$250 \mathrm{~m}, 500 \mathrm{~m}, 1000 \mathrm{~m}, 2000 \mathrm{~m}, 4000 \mathrm{~m}$ と設定し, 近隣の徒歩圈 域の移動から対象地域内の広域の移動までの利用特性を 把握する.

\section{c) Choice 值の規格化}

上述のとおり算出される Choice 值は, 数学的に規格 化の処理がなされておららず，解析範囲が大きくなりそれ に含まれるセグメントの数(Node Count)が大きくなるの に依存して Choice の值も大きくなる性質を持つ. その ため解析範囲の規模が異なる地点同士の指標を単純に比 べることが出来ず，何らかの指標で Choice 值を割るこ とで規格化をする必要がある。

Hillier らの研究 15) では, Choice は以下の式(1)のように Node Count の幕乗に比例して増大寸る性質を持つことが, 経験的に示されている.

$$
\text { Choice }=k \times \text { Node Count }{ }^{a}
$$

本研究で解析した各 Radius 設定の Node Count, Choice の平均值の関係を表-1 - 図-4 に示寸が，ここでも極めて 強、冪乗則が見出された. Hillier らは式(2)で求められる 指数パラメータ $a$ はおよそ $0.2 \sim 2.0$ の間で変動し, この パラメータを用いることは Choice の規格化の一つの方 法であると述べている. 
表-2＼cjkstart街路ネットワークの変遷

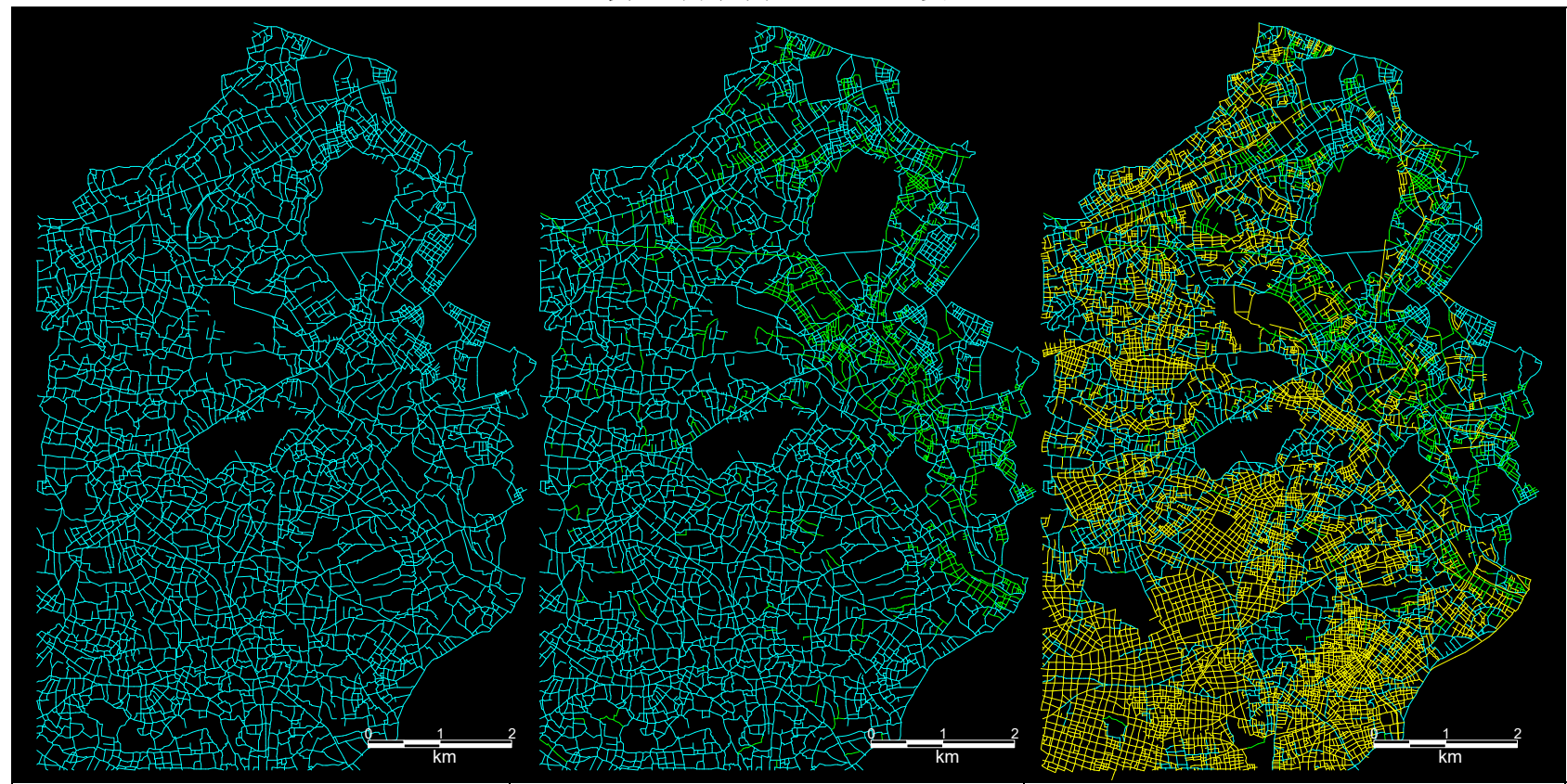

[1] 1909年 :

[2] 1923 年 :

[3] 1937 年

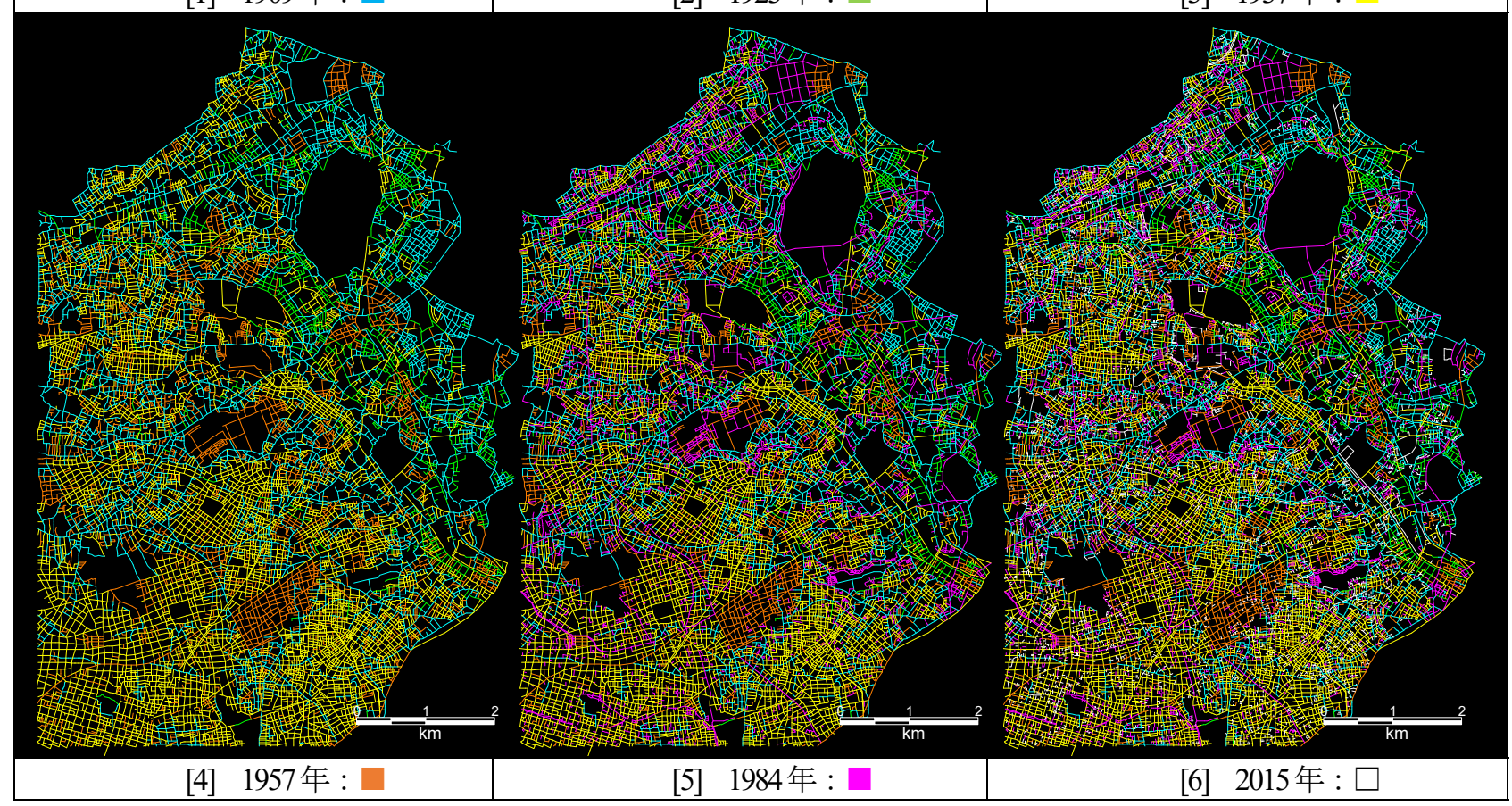

$$
\text { 規格化Choice }: a=\frac{\log (\text { Choice }+1)}{\log (\text { NodeCount })}
$$

本研究ではこの指数パラメータの值を「規格化 Choice」 と定義し，以下の分析で用いることとする(注5).

\section{3. 街路形成年代の特定}

\section{(1) 作業手順}

先述の旧版地形図資料[1]～[5]の紙媒体は大判スキャ ンによってラスタデータ化し，各図郭の四隅の座標(緯 度経度)を基準として GIS 上の座標系(日本平面直交座標
系第 IX 系・JGD2000)に関連付けた。 これを下図として 現在の道路網の形態である基盤地図情報の道路縁データ と重祆合わせながら，幅のある道路として描かれている 場合は道路中心を，一本の線で描かれている場合はその 線をなぞる様にして，手作業にて GIS 上に折れ線オブジ エクトを描画していく.

上記の作業によって，まず[1]1909 年の街路網を作成 し，そのすべての折れ線データに形成年代情報(AGE)と して「1909」の值を与える.[2]1923 年以後は前年代の街 路網データから変化した部分を追加・削除し，追加され た折れ線に当該年代の值を与える.これを順次現在の街 路まで繰り返して作成することで，現在の道路の折れ線 
表-3 2015 年 Segment Map の規格化 Choice 值(Radius $=250 \mathrm{~m}-4000 \mathrm{~m}$ )

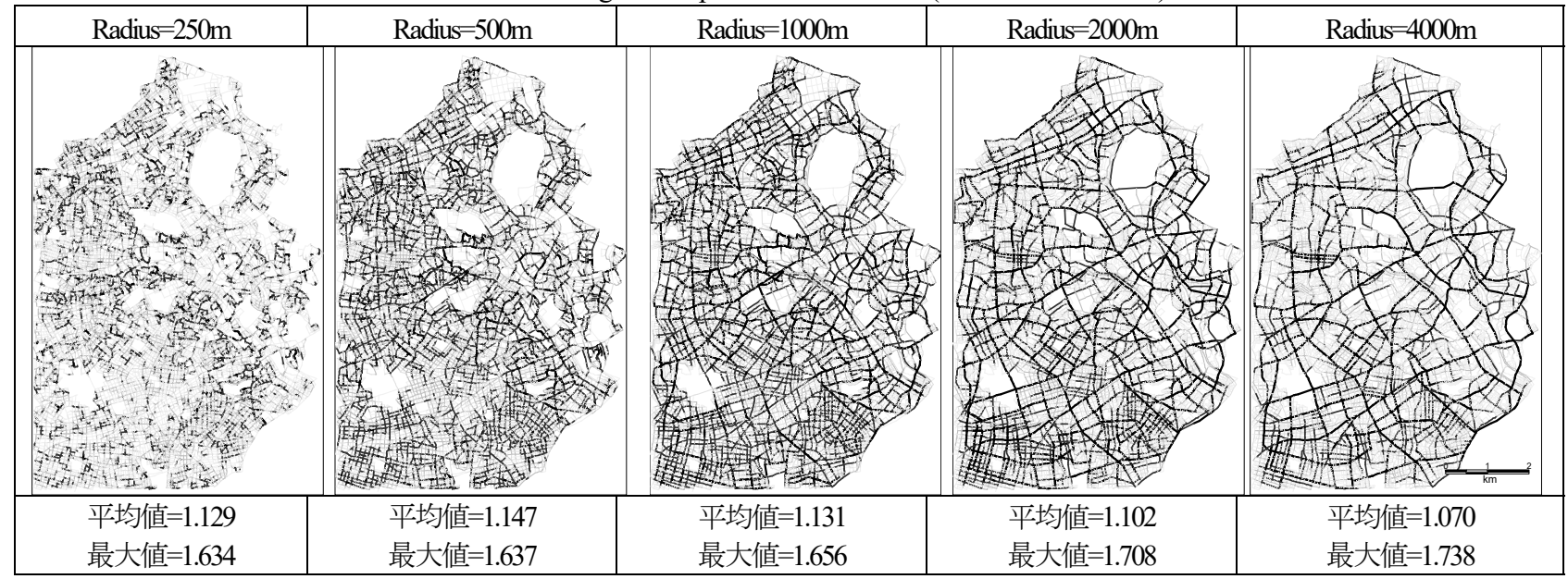

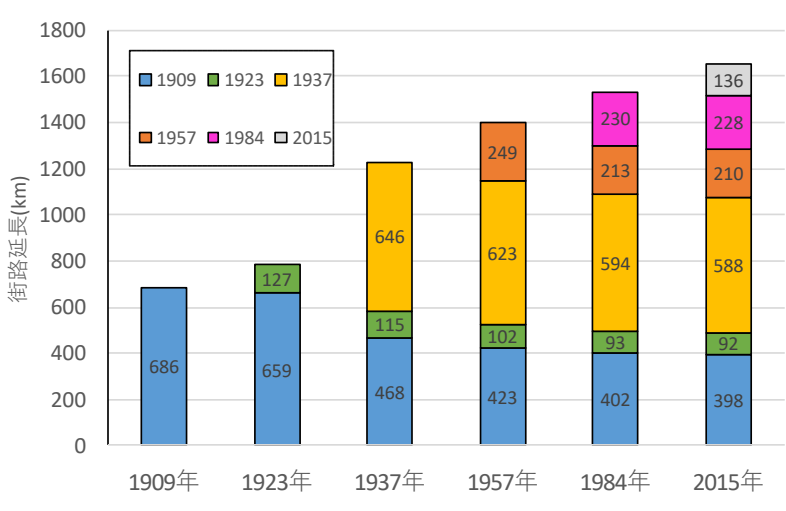

図-5＼cjkstart街路総延長の変化と形成年代の内訳

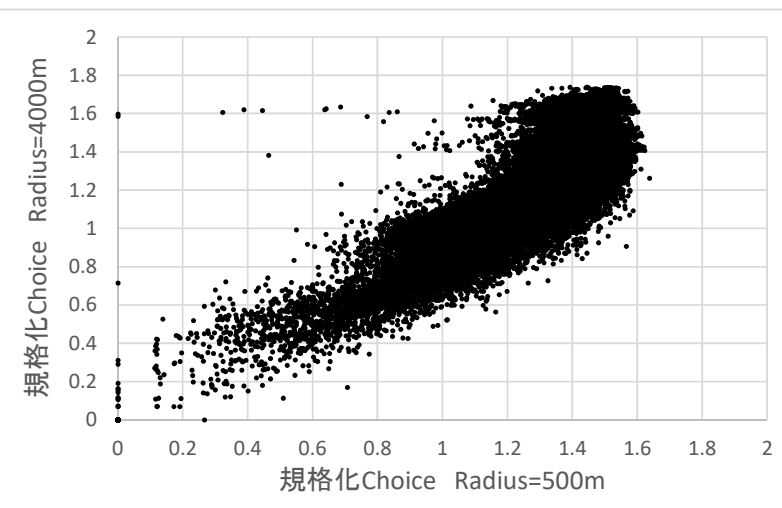

図-6 規格化 Choice Radius $=500 \mathrm{~m}$ と $4000 \mathrm{~m}$ の散布図

表-4 規格化 Choice Radius間の相関係数 (いずれも $1 \%$ 有意， $\mathrm{N}=48519$ )

\begin{tabular}{|l|r|r|r|r|r|}
\hline 規格化 Choice & \multicolumn{1}{|c|}{250} & \multicolumn{1}{c|}{500} & 1000 & 2000 & 4000 \\
\hline Radius=250m & 1 & & & & \\
\hline Radius=500m & 0.973 & 1 & & & \\
\hline Radius=1000m & 0.942 & 0.987 & 1 & & \\
\hline Radius=2000m & 0.919 & 0.969 & 0.992 & 1 & \\
\hline Radius=4000m & 0.903 & 0.954 & 0.980 & 0.995 & 1 \\
\hline
\end{tabular}

すべてにいずれかの年代の情報が与えられる，表-2 に 1909 年から 2015 年の 6 年代の街路パターンの変化を示 于.

\section{(2) 街路延長に関する分析}

Segment の総延長の変化および各年代における街路形 成年代の構成を図-5 に示す. 1909 年時点で総延長約 $685 \mathrm{~km}$ の街路が形成されていたが，2015 年には約 2.4 倍 の約 $1620 \mathrm{~km}$ になっている. 特に 1923 年〜1937年の震災 復興期に新たに建設された街路が約 $646 \mathrm{~km}$ と多く，2015 年現在の街路網の約 35\%を占めている.

各年代で新たに建設された街路の分布は一様ではなく， それぞれに都市計画的な背景を読み取ることができる. 1909 年に存在していた道筋のうち，2015 年まで残存し ているのは約 $398 \mathrm{~km}$ で，その多くは都心側や主要街道 沿い(甲州街道・厚木大山街道など)に存在している. 1923 １957 の各年代では，東京の都市域の拡大・震災 や戦災の復興のための区画整理・耕地整理などによって, まとまって街路が形成された地区があり，現在までそれ らの多くが引き継がれている. 1984・2015 の新しい年代 は，環状 7 号線など主要な都市計画道路が建設されたり 新宿副都心など大規模な再開発が一部でされる一方，小 規模な宅地開発による袋小路を形成する街路が多く，全 域にほぼ均等に分布している.

\section{Segment Anguer 分析による街路利用特性解析}

\section{(1) 2015 年現在の近隣 · 広域の相関}

表-3 に 2015 年現在の Radius $=250 \mathrm{~m} \cdot 500 \mathrm{~m} \cdot 1000 \mathrm{~m} ・$ $2000 \mathrm{~m} \cdot 4000 \mathrm{~m}$ の規格化 Choice 值の主題図と平均・最大 值をまとめて示す. 各主題図を概観すると, Radius= $250 \mathrm{~m}$ では，指標值が高いことを示す黒く太い線であら わされた Segment群が部分ごとに細かくまばらに分布し 
表-5 規格化 Choice值(上段 : Radius $=500 \mathrm{~m}$ - 下段 : Radius $=4000 \mathrm{~m}$ )の年代変化

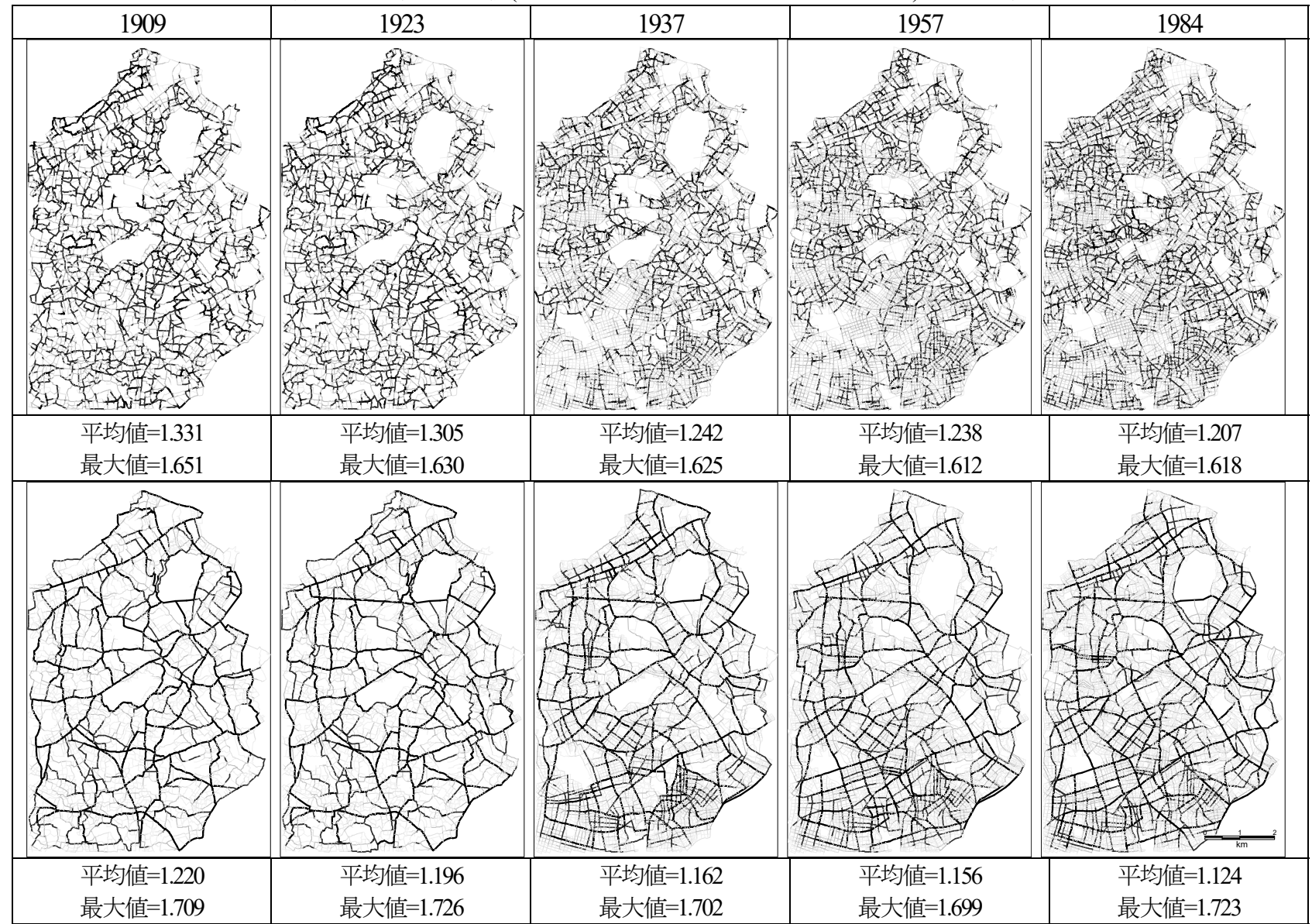

ているのに対し，Radius が大きくなるにつれて指標值の 高い Segment 群は連続的につながるようになり， Radius $=4000 \mathrm{~m}$ では，幹線道路網をなぞるような形でネッ トワークを形成している. 空間的な分布としては近隣と 広域の利用特性には差異が読み取れる一方で，表-4に 示すとおり各指標の間の相関係数 $\mathrm{r}$ はいずれも 0.9 以上 と高い相関性を示している(注 ๑) .以下，紙面の都合上 Radius $=500 \mathrm{~m}$ と $4000 \mathrm{~m}$ に限定して述べる. Radius $=500 \mathrm{~m}(\mathrm{x})$ と $4000 \mathrm{~m}(\mathrm{y})$ の值の散布図(図-6)を見ると高い相関係数の 示すとおり，概ね正の相関関係があることがわかり，す なわち近隣の移動で経路として使われやすい街路は広域 でも比較的使われやすい傾向がある。詳細に見れば,

Radius $=4000 \mathrm{~m}$ の值の方が Radius $=500 \mathrm{~m}$ の值よりも大きい プロットは 9497/48519=約 19.6\%と少なく，さらにその 多くは双方の值が高い領域に集中しており，限定された 街路の指標值が高くなる傾向を示している.

このことについて街路の形成過程の観点から解釈する と，二地点間を結ぶ道を作るときにはできるだけ直線的 に作ろうとするのが自然であるが，遠い地点を結ぶ道 (幹線道路)ほどその傾向が強いのに対して, 近隣の個々 の敷地をつなぐ道ほど部分最適で作られているためその 傾向が弱いことに起因すると考えられる. 本研究の対象 地域においては区画整理によって整然と街路が作られた 地区は別にして，近隣スケール(500m 程度)の地点間の移 動経路では連続した直線的な街路は多くなく，特定の街 路が集中的に経路として選ばれることが無いためある程 度分散するのに対して，1000m, 2000m, $4000 \mathrm{~m}$ と徐々に広 域になるにつれて, 都市計画(道路構造令の基準)によっ て作られた直線的な街路が経路に含まれ，他の地点へ移 動するための経路はそれを経由することが多くなるため, より限定された街路の Choice の值が相対的に高くなる ものと考えられる.

\section{(2) 年代変化}

表-5 に, 1909 年から 1984 年の各年代の Radius $=500 \mathrm{~m}$ と $4000 \mathrm{~m}$ の規格化 Choice 值の主題図と平均值 - 最大值 をまとめて示す。いずれの場合も平均值は年代ごとに小 さくなるのに対して，最大值はほぼ横ばいである.

Radius=500m において指標值の高い Segment は 1923 年 まではほぼ全体に満遍なく分布していたのに対して 1937 年以降は解析範囲の南西側では疎らになっている ことがわかる.これは玉川全円耕地整理事業によって南 西側の地域に広域にわたって整形なグリッドパターンの 街路が形成されたことで，移動経路として利用される街 路が均質化されたことが要因と考えられる.

Radius $=4000 \mathrm{~m}$ では，東西方向に走る甲州街道，厚木大 


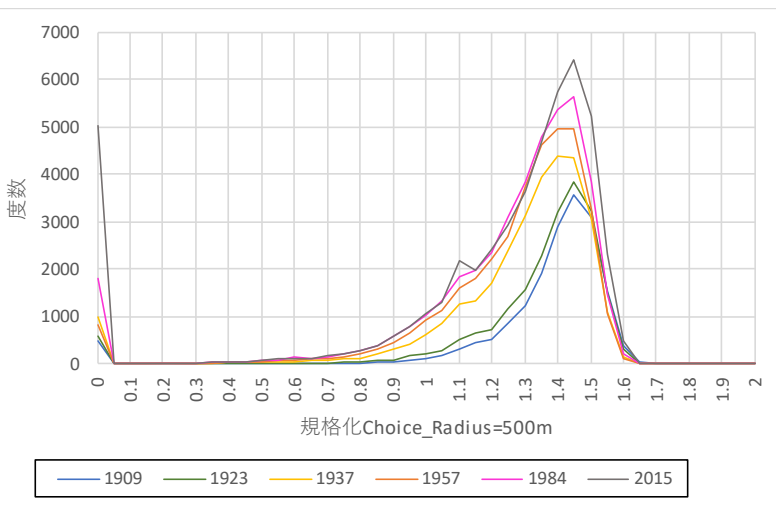

図-7 規格化 Choice (Radius $=500 \mathrm{~m})$ 度数分布の年代変化

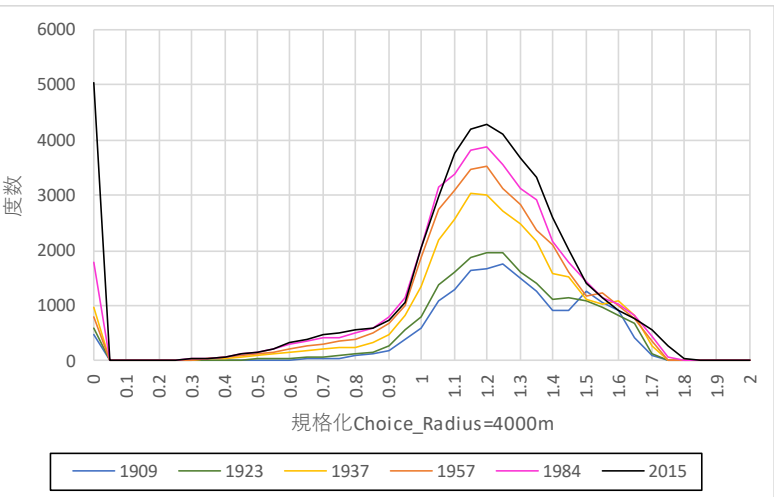

図-8 規格化 Choice (Radius $=4000 \mathrm{~m}$ ) 度数分布の年代変化

表-6 年代別規格化Choiceの平均值と相関比

\begin{tabular}{|c|c|c|c|c|c|c|c|}
\hline \multirow{2}{*}{$\begin{array}{c}\text { Radius } \\
(\mathrm{m})\end{array}$} & 1909 & 1923 & 1937 & 1957 & 1984 & 2015 & 相関比 \\
\cline { 2 - 7 } & П2 \\
\hline 250 & 1.341 & 1.226 & 1.237 & 1.142 & 0.981 & 0.408 & 0.420 \\
\hline 500 & 1.373 & 1.247 & 1.267 & 1.147 & 0.974 & 0.402 & 0.439 \\
\hline 1000 & 1.351 & 1.227 & 1.259 & 1.122 & 0.953 & 0.392 & 0.428 \\
\hline 2000 & 1.307 & 1.194 & 1.234 & 1.095 & 0.932 & 0.384 & 0.408 \\
\hline 4000 & 1.259 & 1.157 & 1.200 & 1.068 & 0.908 & 0.376 & 0.390 \\
\hline
\end{tabular}

山街道などが 1909 年から変わらずに規格化 Choice 值が 高いのに対して，徐々に新たな幹線道路が建設されるの に伴ってそれらが值の高い Segment となっていることな ど，個別の街路の新設・消滅による值の大きい街路の変 化は詳細に見れば特定することが出来るが，全体を俯瞰 するとそのパターンは大きくは変わらない，これは，現 代において広域の移動で利用される幹線道路の多くはい ずれかの年代で新たに都市計画事業として建設されたも のだとしても，それ以前からほぼ同じ位置か近隣に広域 の移動を担う道筋が存在していたことを示している.

規格化 Choice 值のヒストグラムの変化(図-7および図8)を見ると，年代を経るごとに総サンプル数が増加する ためヒストグラムの折れ線の山は大きくなるが，度数が 増加する領域は一様ではない，いずれにおいても，最大 值に近い 1.5 1.7 付近の折れ線はほぼ重なり 1909 年から
現代に至るまでその度数は大きくは増えていないのに対 して，1.0 1.4 付近と 0 の度数が増えている. 規格化 Choice $=0$ の Segmentは即ち行止りの端部の街路であり， 特に 1984 2015 年の間で急激に増加しており先述の通り 小規模な宅地開発による街路形成の影響と考えられる. また中間の 1.0 1.4 付近の Segment は 1937 年に急激に増 加していることが読み取れ，この時期の広域的な区画整 理によって市街地を区画する街路が多く整備された影響 と考えられる。

この分析結果から示唆されるのは，市街地化に伴って 新たに形成される街路の多くは経路として利用されにく い規格化 Choice の值が比較的低い街路であり，逆に経 路として利用されや寸い規格化 Choice の特に高い街路 の多くは市街地化の初期の段階から同様の利用特性を持 った街路で，それらは現在に至るまで存在し続けている という仮説である，次章ではそれを検証するために, 2015 年時点の街路ネットワークを構成する各 Segment の 形成年代ごとに，規格化 Choice との相関性を分析する.

\section{5. 街路形成年代と利用特性との関係性}

$3 ・ 4$ 章の分析によって 2015 年現在の街路網を構成す る全ての Segmentに対して，その形成年代(6年代)と利用 特性(規格化 Choice)が求められた．本章ではこれらの関 係性を，カテゴリーデータと連続データとの相関性を表 す指標である相関比 $\eta^{2}$ を用いて分析する.

統計解析パッケージソフト SPSS を用いて，各 Radius 設定ごとの規格化 Choice を従属変数, 街路形成年代を 独立変数として相関比を求めた結果を表-6 に示す. 分 散分析の $\mathrm{F}$ 検定の結果はいずれも $1 \%$ 有意水準を満たし た. 形成年代ごとの規格化 Choice 平均值は 1909 年 $\rightarrow$ 1937 年 $\rightarrow 1923$ 年 $\rightarrow 1957$ 年 $\rightarrow 1984$ 年 $\rightarrow 2015$ 年の順に低く なり, サンプル数が少ない 1923 年を除いて年代の古い 街路ほど高く，相関比 $\eta^{2}$ の值はいずれの Radius の場合 においても 0.4 程度と，弱いながらも相関が見られ，そ の值は Radius $=500 \mathrm{~m}$ が最も高く, Radius $=4000 \mathrm{~m}$ が最も低 かった.

古い年代から現在まで残存している街路は媒介中心性 の高い，すなわち移動に際して経路として選ばれやすい 街路が多く，新たに建設された街路は媒介中心性の低い， すなわち街区を区画したり行き止まりを形成したりする 街路が多いということを，4 章の分析では年代間の変化 から推測したが，本分析によって現在の街路ネットワー クの形態的特性からも明らかにするものである.

規格化 Choice 平均值の比較による傾向は，広域も近 隣も大きな違いは見られないが，相関比の若干の差異は， 分散の程度の差異によるものである．新しい年代に作ら 
れた街路は区画街路や行き止まり街路が主であるが，都 市計画道路として整備された幹線・補助幹線街路は，広 域において規格化 Choice の值が高く，その数は少ない ものの分散を大きくし，相関比が相対的に低くなる結果 となったと考えられる.

\section{6. 結論}

本研究では旧版地形図を基に，過去から現在まで 6 年 代における街路パターンを，変化・不変の比較が可能な 形で GIS 上に整備・可視化したことで，現代の街路パタ ーンを構成する各街路の形成年代を個々の街路単位で特 定することができた。 また，Space Syntax 理論の SegmentAngler 分析によって Choice 值(媒介中心性指標)を算出し, 更にその規格化をすることによって，年代間での媒介中 心性指標の変化の傾向を統計的に比較・分析することが 可能となった.

現代の街路パターンにおける，各街路の形成年代と媒 介中心性指標との関係性について，平均値の比較，相関 比の分析を行った結果, 形成年代の古い街路ほど媒介中 心性指標が平均的に高いことが明らかになった．本研究 で分析した 6 年代は，分析対象地域における都市計画・ 市街地形成の重要な節目を反映したものであり，固有の ものであるが，まず幹となる街路が存在し，枝葉となる 街路が徐々に形成されていくという自然な街路パターン 形成のプロセスとして一般的なものと考えられる. 本研 究ではその「幹」「枝葉」という街路の機能的な特性を 経路としての利用特性を表す媒介中心性(規格化 Choice) によって定量的に明らかにし，統計的に検証した点が成 果と考えられる.

また近隣と広域の移動圈域に対応した媒介中心性指標 の対比によって，上記の傾向には若干の分散の差異があ ることも明らかにした。これは 4 章(1)および5章で考察 した通り，特に戦後に整備された都市計画道路がより広 域において媒介中心性が高いことが影響しているものと 考えられる.

本研究では主題図の俯瞰的な読み取りと統計によって 全体的な傾向を述べるにとどまっている．新たな街路が 建設されたことによる周辺の古い街路の利用特性の変化, 地区ごとの形成年代の混在特性と利用特性の関係などを 個別に分析することは，地区レベルでの街路計画の検討 に有用な知見を示すと思われるが，今後の課題としたい.

\section{補注}

(注1) 昭和 11 年に北多摩郡烏山村と砧村が世田谷区に 編入され，ほぼ現在の 23 区の範囲となる.

(注2) 他の縮尺の地形図と比較すると，1/25000 や
1/50000 地形図では，より広範囲かつ古い年代のも のが発行されているが，地区内の細街路まで確認 することはできない.また明治 13 年〜19 年に測 量・刊行されたいわゆる「迅速図」もその名の通 り簡易的な測量に基づくものであり，縮尺 $1 / 20000$ であるため街路の特定のための精度が不十分であ ることから, 本研究の分析には適さないと判断し た.

(注3)このうち戦前の 3 年代[1]〜 [3]については「明 治・大正・昭和 東京 1 万分の 1 地形図集成」(柏 書房)の図を用いた。また戦後期[4]については「戦 災復興期 東京 1 万分の 1 地形図集成」(柏書房) に収録されている図と, 国土地理院にて謄本発行 された図の両方を用いて昭和 32 年の街路ネットワ ークを再現した。[5]については国土地理院で当該 地域の図郭を謄本発行した図を用いた。[6]現代に ついては国土地理院の基盤地図情報よりベクター データとして道路縁形状を取得するとともに,

「地理院地図」を下図として, 現在の道路ネット ワークを作成した。

(注4) 規格化の一つの考え方として，グラフ理論で一般に 用いられる Freeman によって提唱された媒介中心性 $C_{b}$ (k)があり，それは以下の式で定義される.

$$
C_{b}(k)=\sum_{i \neq j \neq k} \sum_{i \neq j \neq k} \frac{g_{i j(k)}}{g_{i j}}
$$

ここに， $g_{i j}$ は解析範囲に含まれるノード $i$ から $j$ にいた る最短経路の数, $g_{i}(k)$ はそのうち当該ノード $k$ を通る 経路の数である。一般的には「最短経路」とする距離 の定義に，経路の実距離あるいは移動時間などを用い るのに対して, Segment Anguler分析の Choiceは，累積折 れ曲がり角度を用いた場合の $g_{j}(k)$ と定義できる。これ を当該範囲に含まれるノード間の全ての組み合わせの 数: $g_{i j}$ で割ることで規格化を図っており，その数はノー ドの総数を $N$ とすると式(4)のように求められ, およそ $N$ の 2乗のスケールの数であることがわかる.

$$
\sum_{i \neq j \neq k} g_{i j}=(N-1)(N-2)
$$

Freeman の媒介中心性指標は，当該ノードをハブとし て放射状に他のノードが直接連結し，かつ他のノード 同士を結ぶリンクが存在しないときのみ, 最大值の 1 の值を取り得るが，現実の都市空間の街路ネットワー クではそのようなノード(交差点であっても街路リンク =セグメントであっても)は想定できず，実際に分子の 当該ノードを通る経路の数 $=g_{\text {i⿹ }}(k)$ は分母に対して相当 小さく，その確率分布は正規分布に従わない. それに 対して本論で算出した指数パラメータは図-6・7 に示す とおり正規分布に近い確率分布を取り, 相関係数, 相 関比などの分析に適するため，指数パラメータを用い た.

(注5) 規格化 Choice 值は定義上，行止りの端部において 0 , 上述の Freeman の媒介中心性指標と同様の条件で理論 上の最大值 2.0 を取る以外は，あくまで相対的な経路の 集中度を表すものである. 本研究では平均值・最大值 の変化・比較や度数分布の変化などから, 全体的傾向 を統計的に分析するもので，個別空間の指標值と実態 としての街路利用特性との対応関係については今後の 検討課題である.

(注6) 解析範囲(Radius)を変えた指標同士の相関係数が高い のは，広域の解析範囲において計算される二地点間の 経路の組合せは，狭域の解析範囲において計算される 
経路の組合せも包含したものであるため，狭域におい て高い值を示す Segment は広域においても高い值を持 ちや寸い.これは本研究対象地に固有のものではなく, 指標の持つ普遍的な傾向である.

\section{参考文献}

1) 小場瀬令二：非計画的市街地の道路網形成に関する 研究一東京・世田谷区の場合について一，第 18 回日 本都市計画学会学術研究発表会論文集, pp. 337-342, 1983.

2) 西村卓也，高松誠治，大口敬：GIS を活用した東京の 街路構造変遷に関する研究，土木学会論文集 D3 (土 木計画学), Vol. 68, No. 5(土木計画学研究・論文集第 29 巻), pp.I_407-I_416, 2012.

3) 木川剛志, 古山正雄 : 都市エントロピー係数を用い た都市形態の解析手法一パリの歴史的変遷も考察を 事例として一，日本都市計画学会論文集，No. 39-3, pp. 823-828, 2004.

4) 木川剛志, 古山正雄 : スペース・シンタックスを用 いた「京都の近代化」に見られる空間志向性の分析 一京都都市計画道路新設拡築事業における理念の考 察一, 日本都市計画学会論文集, No. 40-3, pp. 139144, 2005.

5) 木川剛志, 古山正雄 : スペース・シンタックスを用 いた地方都市の近代化に伴う形態変容の考察一滋賀 県大津市における近代化プロセスを事例として一, 日本都市計画学会論文集, No. 41-3, pp. 229-234, 2006.

6) 木川剛志, 加嶋章博, 古山正雄 : スペース・シンタ ックスを用いた台北市の近代化過程の考察一日治時 代(1895-1945)中期における西門町形成過程の形態学 的分析を中心として, 日本都市計画学会論文集, No. 42-3, pp. 373-378, 2007.

7) 猪八重拓郎，永家忠司，外尾一則：駅を核とする道 路網の形成過程とそのまとまりに関する研究一佐賀 駅とその周辺市街地を事例としたスペース・シンタ ックス理論の応用, 日本都市計画学会論文集, No.
43-3, pp. 541-546, 2009.

8) 福山祥代, 羽藤英二：バルセロナの歴史的発展過程 と歩行者の行動圈域を考慮した広場一街路のネット ワーク分析，土木学会論文集 D1 (景観・デザイン), Vol. 68, No. 1, pp. 13-25, 2012.

9) 宮脇勝 : ランドスケープと都市デザインー風景計画 のこれからー, pp. 48-51, 朝倉書店， 2013.

10) 松倉史英，宮脇勝：江戸東京最都心部における道路 と街区の形成年代に関する研究－東京都中央区全域 及び月島地区の街区の歴史性, 日本都市計画学会論 文集，No. 41-3,pp. 953-958, 2006.

11）北岡勝江，宮脇勝：台東区における寺町の道路と街 区と寺院の歴史的変遷に関する研究一台東区全域と 谷中・浅草を事例に一, 日本都市計画学会論文集, No. 43-2, pp673-678, 2008.

12）槇文彦，高谷時彦，若槻幸敏，大野秀敏：見えがく れする都市，鹿島出版会，1980.

13) Hillier, B. and Hanson, J.: Social Logic of Space, Cambridge University Press, 1984.

14) 高野裕作，佐々木葉：Space Syntax を用いた都市空間 構造研究の動向と展望, 土木学会景観・デザイン研 究講演集, No. 6, pp. 183-190, 2010.

15) Hillier, B., Yang, T. and Turner, A.: Advancing DepthMap to advance our understanding of cities; comparing streets and cities, and streets to cities, Proceedings of 8th Space Syntax Symposium, pp. 18-27, 2012.

16）西村卓也，石倉智樹，小根山裕之，鹿田成則：街路 の利用特性と接続特性に関する実証研究，土木学会 論文集 D3 (土木計画学), Vol. 70, No. 5 (土木計画学研 究・論文集第 31 巻), pp. I_279-I_293, 2014.

17) 高松誠治, 堀口良太, 赤羽弘和：道路網の位相幾何 学的評価尺度を導入した交通事故リスク推計モデル の構築, 交通工学, Vol. 44, No. 1, pp. 54-62, 交通工学 研究会, 2009.

(2017. 6.8 受付)

\section{A STUDY OF RELATION BETWEEN THE HISTORICAL CHARACTER AND USABILITY ON STREET PATTERN BY APPLYING SPACE SYNTAX}

\section{Yusaku TAKANO and Yoh SASAKI}

Existing urban space is constructed of a variety of streets that have the unique historical characters, for example old paths existing from pre-modern age, urban roads authorized in city plan, small allays built by urban sprawl. On the other hand, each street currently has usability on street network such as main street, commercial street, grid road in residential district. On planning street network, it is important to demonstrate the relation between these characteristics.

The study field is Meguro Ward, Shibuya Ward and the periphery, where the urban area of Tokyo has exploded during modernization. In this study, we analyzed old edition topographic maps to identify the construction age of each street and applied Space Syntax to analyze the betweenness usability on street pattern. And then, we calculate the correlation ratio between these indices. As a result, it is revealed that older age streets have higher value of betweenness usability on neighborhood scale. 